\title{
Transduction of Folate Receptor cDNA into Cervical Carcinoma Cells Using Recombinant Adeno-associated Virions Delays Cell Proliferation In Vitro and In Vivo
}

Xin-Lai Sun, Brian R. Murphy, Qing-Jun Li, Sharada Gullapalli, Janet Mackins, Hiremagalur N. Jayaram, Arun Srivastava, and Aśok C. Antony

Department of Medicine, Division of Hematology-Oncology, Indiana University School of Medicine, Indianapolis, Indiana 46202

\begin{abstract}
Although folate receptors (FRs) mediate folate uptake into cells, the independent role of FRs in cell proliferation remains unclear. We tested the hypothesis that transduction of FR cDNA in sense or antisense orientation using recombinant adeno-associated virus modulated FR expression and altered proliferation of cervical carcinoma cells (which constitutively overexpress FR genes). We determined that the integration of recombinant adeno-associated virions was not site specific. When compared with untransduced cells, sense and antisense FR cDNA-transduced cells exhibited an increase and decrease in FR mRNA and FR expression on the cell surface, respectively. However, when compared with antisense FR cDNA-transduced and untransduced cells, sense FR cDNA-transduced cells exhibited statistically significant $(a)$ increases in total FRs, $(b)$ smaller colonies, $(c)$ lowered cell proliferation in vitro, and $(d)$ less tumor volume with dramatic prolongation of tumor doubling times (225.6 h vs. 96 h) after transplantation into nude mice. Finally, $(f)$ using single cell-derived transduced clones, an inverse relationship between cell proliferation and FR expression was established $(r=0.90, P<0.001)$. Thus, transduction of sense/antisense FR cDNA into cervical carcinoma cells modulated expression of FRs and had an impact on cell proliferation in vitro and in vivo. (J. Clin. Invest. 1995. 96:1535-1547.) Key words: tumor growth - gene transfer • genomic integration - transplantation • doubling time
\end{abstract}

\section{Introduction}

The essential role of intracellular folates in one-carbon metabolism is well established (1). In the past decade, we and others demonstrated that the mechanism of cellular entry of physiologic folates into normal and several malignant cell lines in-

A portion of these studies was presented in abstract form at the American Society of Hematology Meeting in December 1992 at Anaheim, CA, and at the National Meeting of the American Society for Clinical Investigation in May 1994 at Baltimore, MD.

Address correspondence to Aśok C. Antony, M.D., Department of Medicine, Division of Hematology-Oncology, 975 West Walnut Street IB 442, Indiana University School of Medicine, Indianapolis, IN 462025121. Phone: 317-274-3589; FAX: 317-274-0396.

Received for publication 20 June 1994 and accepted in revised form 9 May 1995.

J. Clin. Invest.

(C) The American Society for Clinical Investigation, Inc.

0021-9738/95/09/1535/13 \$2.00

Volume 96, September 1995, 1535-1547 volves interaction with cell surface folate receptors (FRs), ${ }^{1}$ which are anchored to the membrane by glycosyl-phosphatidylinositol (GPI) anchors (reviewed in references 2-4). Earlier, we also showed that the interaction of anti-FR IgG with FRs on hematopoietic erythroid, myeloid, macrophage, and megakaryocytic progenitors led to a profound stimulatory effect on cell proliferation that was independent of anti-FR antibodymediated induction of megaloblastosis and intracellular folate deficiency $(5,6)$. Thus, these data suggested a role for FRs in constitutive control of proliferation from one of two possibilities: either the antibody perturbed a normal inhibitory role of the FRs on cell proliferation, or alternatively, the antibody accentuated a normal function of the FRs in constitutive stimulation of cell proliferation (4). In either case, an important issue is whether FRs have a similar role in malignant cells.

Recent studies documented alterations in cell proliferation following transfection of sense FR cDNA into cells that do not constitutively express FRs (7-10). Thus, transfected cells exhibited greater proliferation and survival when compared with controls. Because proliferation of transfected cells was assessed in low extracellular/physiologic (nanomolar) folate concentrations, it is unclear whether these findings were caused by the independent effects of $(a)$ a greater concentration of intracellular folates accumulated by FR cDNA-transfected cells (which prevented folate-deficient cell death), $(b)$ a proliferative signal generated at the level of the FRs per se, or $(c)$ a combination of both.

One approach to begin to sort out these possibilities is to introduce FR cDNA into cells in a sense or antisense orientation and determine the functional consequences of over- and underexpression on cell proliferation at micromolar extracellular folate concentrations, which allows passive diffusion of folic acid intracellularly (11). However, rather than transfection, we wished to transduce FR cDNA after its encapsidation into an infectious virion in anticipation that in vitro data may eventually be translated in vivo (12).

A wild-type (wt) nonpathogenic human parvovirus (13), the adeno-associated virus 2 (AAV), integrates into the host genome by recombination between inverted terminal repeats (ITRs) of AAV and host DNA (14-17). Although earlier studies demonstrated random integration of recombinant AAV [(r)AAV] into the human genome, two groups recently identified site-specific integration of the wt-AAV genome into human

1. Abbreviations used in this paper: AAV, adeno-associated virus 2; Ad2, human adenovirus 2; FACS, fluorescence-activated cell sorting; FR, folate receptor; GPI, glycosyl-phosphatidylinositol; GPI-PLC, GPIspecific phospholipase C; ITR, inverted terminal repeat; PteGlu, ptesoylglutamic acid; (r), recombinant; RVS, recombinant virus stock; wt, wild type. 
chromosome 19q13-qter (18-20), while another identified integration into chromosome 17q (21). Therefore, AAV-based vectors have the potential for safe and efficient use in human gene therapy (14-17), and recent studies involving the introduction of physiologically relevant genes have been published (22-24).

Accordingly, we employed (r) AAV (which retained only ITRs of wt-AAV) to transduce sense/antisense FR cDNA into cervical carcinoma cells, which constitutively overexpressed FRs even while growing in micromolar extracellular folate concentrations. Using this model, we specifically addressed three questions: (a) Is site-specific integration retained in our (r)AAV? (b) Can transduction of physiologically relevant genes significantly modulate expression of constitutively overexpressed genes (such as FRs in cervical carcinoma cells)? (c) Does altering basal FR expression lead to any functional consequences in cells transduced with sense versus antisense FR cDNA? In addition to studies with clonal mixtures and single-cell-derived clones of sense and antisense FR cDNAtransduced cells in vitro, complementary studies on tumor growth in mice transplanted with these cells were also carried out to confirm the in vitro data.

\section{Methods}

\section{Materials}

All cell culture media, sera, antibiotics and other additives, PBS, as well as Escherichia coli DH10B-competent bacteria, were obtained from GIBCO BRL (Gaithersburg, MD). Restriction endonucleases, $T_{4}$ DNA ligase, the in vitro transcription kit, and fluorescein isothiocyanateconjugated goat anti-mouse IgG, and (r)GPI-specific phospholipase C (GPI-PLC) were obtained from Boehringer Mannheim (Indianapolis, IN). Mouse nonimmune IgG was obtained from Pierce (Rockford, IL). $\left[3^{\prime}, 5^{\prime}, 7,9-{ }^{3} \mathrm{H}\right]$ Pteroylglutamic acid $\left(\left[{ }^{3} \mathrm{H}\right] \mathrm{PteGlu}\right)$, potassium salt, sp act $50 \mathrm{Ci} / \mathrm{mmol} ;{ }^{32} \mathrm{P}-\mathrm{dCTP}$, sp act $\sim 3000 \mathrm{Ci} / \mathrm{mmol} ;{ }^{32} \mathrm{P}-\mathrm{UTP}$, sp act $\sim 8000 \mathrm{Ci} / \mathrm{mmol}$; and $\left[{ }^{35} \mathrm{~S}\right]$ cysteine, sp act $\sim 1000 \mathrm{Ci} / \mathrm{mmol}$, were obtained from Amersham Corp. (Arlington Heights, IL). All chemicals were of the highest analytical grade and, unless stated otherwise, were from Sigma Chemical Co. (St. Louis, MO).

\section{Plasmids and viruses}

pc32, a pUC 8 plasmid containing full-length human FR cDNA (25), was a generous gift from Dr. P. C. Elwood (Medicine Branch, National Cancer Institute, National Institutes of Health, Bethesda, MD). pAAV/ NEO and pAAV/Ad, a helper plasmid containing AAV genes necessary for replication (26), were generously provided by Dr. R. J. Samulski (University of North Carolina, Chapel Hill, NC). pTwu.G1 $(27,28)$ was a kind gift of Dr. R. H. Schloemer, and human adenovirus 2 (Ad2) was kindly provided by Dr. K.H. Fife (both from Indiana University School of Medicine, Indianapolis, IN). A pBluescript-derived plasmid containing the 0.3-kb right flanking DNA fragment (rff-DNA) related to wt-AAV integration was kindly provided by Dr. K. I. Berns (Cornell University Medical College, New York, NY) (18).

\section{Origin of cells}

KB cells, passage 363 , an established line of human nasopharyngeal carcinoma cells, were grown at $37^{\circ} \mathrm{C}$ as described $(29,30)$. The parent cells, which were contaminated with HeLa cell markers as early as 1976 $(31,32)$, were subcloned in $1 \%$ methyl cellulose, and single clones were directly aspirated under microscopic visualization. One such cell line has been in continuous passage since 1985. In 1992, one of several individual clones of cells was further subjected to two rounds of limiting dilution before use in these experiments. Karyotypic analysis revealed that it was a HeLa cell-derived line because it contained none of the classic markers of KB cells $(31,32)$, and HeLa markers 2 and 3 (three copies) were present (data not shown). This clone is designated HeLa$\mathrm{IU}_{1}$ in this report to distinguish it from parent $\mathrm{KB}$ cells. These cells contained GPI-linked FRs ( see Fig. 4,e), which are localized on plasma membranes and membranes surrounding organelles, as determined by immunohistochemistry and immunofluorescence with anti-FR antiserum (data not shown), similar to that described earlier (29). The cellular FRs, which are predominantly alpha isoforms as determined by reverse transcription-PCR, participate in transport of folates into cells (data not shown) ${ }^{2,3}$ In addition, the FR cDNA we transduced into cells was the $\alpha$-FR isoform. When transfected into cells, this FR cDNA isoform has been shown to allow cells that do not constitutively express FRs to tolerate growth in very low folate media $(7,8)$ and increases the sensitivity of cells to methotrexate (9), consistent with the concept that this FR isoform plays an important role in cellular folate transport.

\section{Analysis of the extent of GPI anchoring of FRs in} untransduced, sense, and antisense cells

The FRs of cells were biosynthetically labeled by $\left[{ }^{35} \mathrm{~S}\right]$ cysteine, and their conversion from a hydrophobic to hydrophilic species by GPIPLC was determined as follows. Briefly, $2 \times 10^{6}$ cells at $\sim 80 \%$ confluency were rinsed three times with Dulbecco's (D)-PBS and starved for $18 \mathrm{~h}$ in $8 \mathrm{ml}$ cysteine-free MEM containing $10 \%$ dialyzed FCS before being pulsed with $\left[{ }^{35} \mathrm{~S}\right]$ cysteine $(400 \mu \mathrm{Ci}$ in $4 \mathrm{ml}$ of cysteine-free media) for $8 \mathrm{~h}$ at $37^{\circ} \mathrm{C}$. After washing with D-PBS containing $20 \mathrm{mM}$ EDTA, $100 \mu \mathrm{g} / \mathrm{ml}$ phenylmethylsulfonyl fluoride, and $1 \mu \mathrm{g} / \mathrm{ml}$ aprotinin (buffer A), the cells were solubilized in $1 \mathrm{ml}$ buffer A containing $1.5 \%$ Triton X-114 at $4^{\circ} \mathrm{C}$ for $24 \mathrm{~h}$. After centrifugation at 13,600 $\mathrm{g}$ for 15 min at $4^{\circ} \mathrm{C}$, the supernatant containing ${ }^{35} \mathrm{~S}$-labeled FRs was subjected to two cycles of temperature-induced phase separation (33) to remove free $\left[{ }^{35} \mathrm{~S}\right]$ cysteine. Each cycle involved incubation at $37^{\circ} \mathrm{C}$ for $10 \mathrm{~min}$, followed by centrifugation at $13,600 \mathrm{~g}$ for $5 \mathrm{~min}$ at $22^{\circ} \mathrm{C}$, aspiration of the supernatant, followed by reconstitution of the remaining Triton $\mathrm{X}$ 114 micellar phase with $1 \mathrm{ml}$ buffer $\mathrm{A}$. The solubilized cell membrane extracts containing ${ }^{35} \mathrm{~S}$-labeled FRs among other hydrophobic radiolabeled proteins $(120 \mu \mathrm{g})$ were then incubated with $0.66 \mathrm{U}$ GPI-PLC in $100 \mu$ l buffer A containing $1 \%$ Triton X-114 for $1 \mathrm{~h}$ at $37^{\circ} \mathrm{C}$, followed by addition of $0.5 \mathrm{ml}$ of this buffer and cooling to $4^{\circ} \mathrm{C}$. After temperature-induced phase separation, the aqueous and micellar phases were separated. After addition of buffer $A$ to the micellar phase to a final volume of $0.5 \mathrm{ml}$ and Triton $\mathrm{X}-114$ to the aqueous phase to achieve a final concentration of $1 \%$, the samples were individually reacted at $4^{\circ} \mathrm{C}$ with $20 \mu \mathrm{l}$ crude nonimmune serum for $2 \mathrm{~h}$, followed by reaction with $200 \mu \mathrm{l}$ of IgGsorb (Enzyme Center, Boston, MA) for $2 \mathrm{~h}(6,34)$. After sedimentation of IgGsorb, the supernatants were reacted with $20 \mu \mathrm{l}$ crude anti-PFR antiserum (35) at $4^{\circ} \mathrm{C}$ overnight. After sedimentation of ${ }^{35} \mathrm{~S}$-labeled FR-antibody complexes using IgGsorb, the samples were analyzed on $12.5 \%$ SDS-PAGE (6) followed by fluorography. ${ }^{3}$

Construction of ( $r) A A V$ containing $F R$ cDNA in the sense orientation ( $p B A R S)$ and in the antisense orientation (pAnti-BARS) (Fig. 1)

All recombinant DNA methods were as described (36).

Construction of pBARS. The 1.1-kb full-length human FR cDNA was recovered by digesting the original plasmid pc32 with EcoRI. The pUC 9 vector with the herpes simplex virus thymidine kinase (TK) promoter from plasmid pTwu.G1 was dissociated from $n e o^{R}$ by digesting with BgIII plus BamHI. The blunt-ended 1.1-kb FR cDNA fragment and the 2.9-kb pUC 9/TK promoter fragment were ligated. After transformation of competent $E$. coli $\mathrm{DH} 10 \mathrm{~B}$ and selection, plasmids containing FR cDNA in the sense orientation in relation to the TK promoter

2. Sun, X-L., K. Gharehbaghi, H. N. Jayaram, and A. C. Antony, manuscript in preparation

3. Li, Q.-J., X.-L. Sun, and A. C. Antony, manuscript in preparation. 

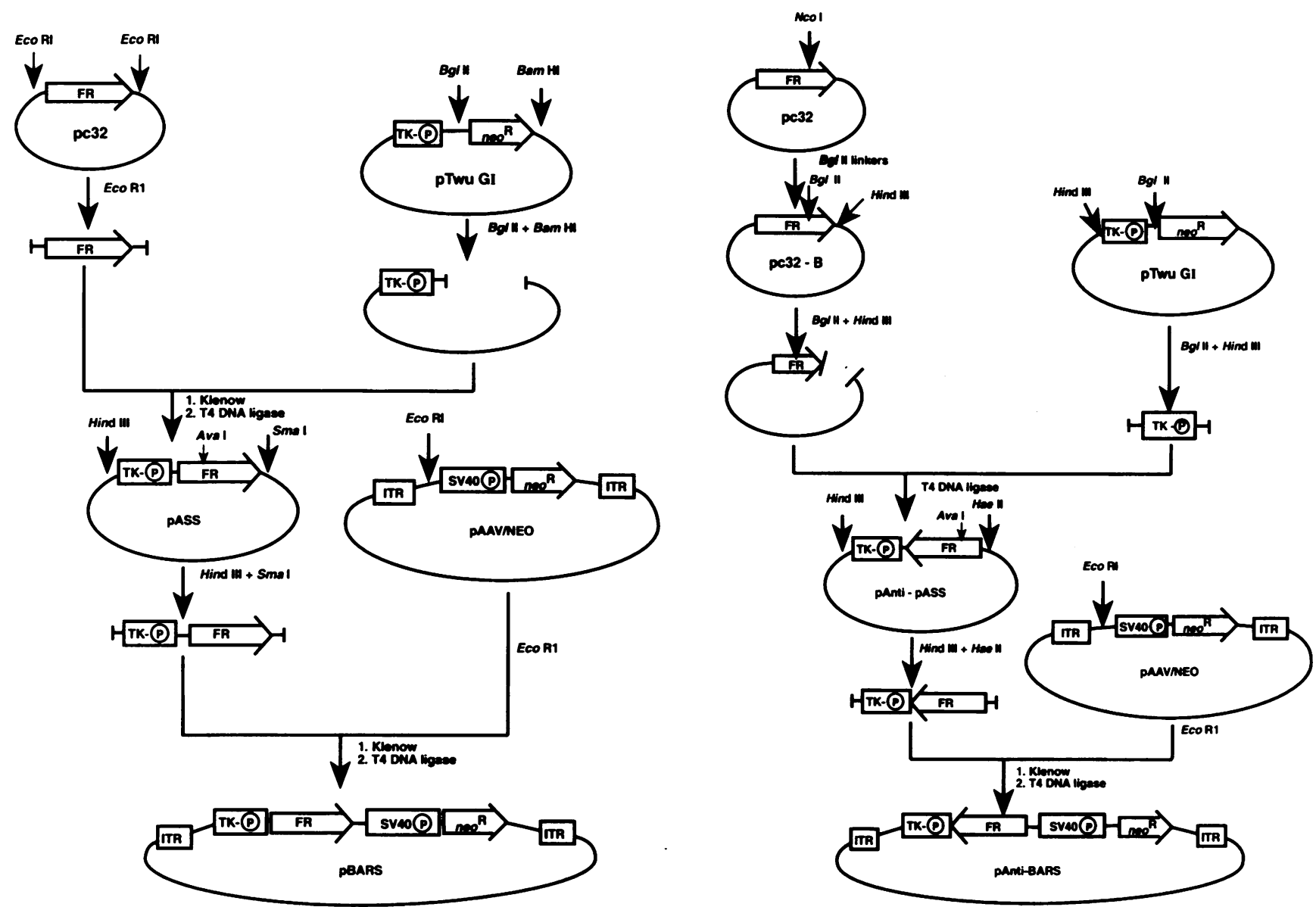

Figure 1. Overall strategy for construction of the ( $\mathrm{r}$ )AAV-based plasmids containing the 1.1-kb FR cDNA in the sense orientation (pBARS, left) and the 1.06-kb FR cDNA in the antisense orientation (pAnti-BARS, right) in relation to the TK promoter. The plasmids used and each experimental step are detailed in Methods.

(designated pASS; see Fig. 1, left) were identified by digestion with AvaI, which cleaves the sense FR cDNA-oriented construct into 3.25 $\mathrm{kb}$ and $0.75-\mathrm{kb}$ fragments. The plasmid $\mathrm{pAAV} / \mathrm{NEO}$ is a pEMBL derivative that consists of a $n e o^{R}$ gene driven by the simian virus 40 (SV40) early promoter, flanked by AAV ITRs. The 1.35-kb fragment containing the TK promoter plus sense FR cDNA was isolated from pASS by digestion with HindIII and SmaI, blunt-ended, and ligated to PAAV/ NEO, which was linearized by digestion with EcoRI and blunt-ended to construct pBARS.

Construction of pAnti-BARS. Position 1060 of FR cDNA in pc32 has a unique NcoI site. Therefore, after digesting pc32 with NcoI and blunt-ending, an 8-mer BglII linker was ligated at this NcoI site. The resultant plasmid contained a BglII site at position 1060 of the FR cDNA (designated pc32-B; see Fig. 1, right). After digestion with BglII plus HindIII, a 3.69-kb fragment (containing the pUC 8 vector plus the initial 1060 bp of the FR cDNA) was isolated. The 250-bp TK promoter was isolated from pTwu.G1 by digestion with BglII plus HindIII and ligated to the 3.69-kb fragment described above. The resultant plasmid (pAnti-pASS; see Fig. 1, right) consisted of the TK promoter driving the FR cDNA in the antisense orientation. The 1.55-kb fragment containing the TK promoter linked to the antisense FR cDNA was isolated by digestion with HaeII plus HindIII, blunt-ended, and ligated to PAAV/ NEO, which was digested with EcoRI and blunt-ended to construct pAnti-BARS. Verification that AAV ITRs flanked the TK promoter that preceded sense or antisense FR cDNA and SV-40 promoter-driven $n e o^{\mathrm{R}}$ gene was carried out by analysis using various restriction endonucleases (data not shown).

\section{Preparation of recombinant virus stocks}

DNA rescue/replication assays $(26,37-39)$ of pBARS and pAntiBARS identified the following optimal conditions for preparation of RVS: 10 plaque-forming units of Ad2, $2 \mu \mathrm{g} \mathrm{AAV/Ad,} 2 \mu \mathrm{g}$ pBARS or pAnti-BARS, and incubation of cells in $1 \mathrm{ml}$ transfection media for 30 min followed by culture for $60 \mathrm{~h}$. Recombinant virus stocks (RVS) prepared from pBARS (RVS-BARS) and pAnti-BARS (RVS-AntiBARS) were quantified before use, as described $(26,37)$.

\section{Transduction and selection of geneticin-resistant cells}

After washing 70\% confluent cells three times with $10 \mathrm{ml}$ PBS/wash, cells were infected with RVS-BARS or RVS-Anti-BARS at $37^{\circ} \mathrm{C}$ for $1 \mathrm{~h}$ as described (26). After cells were cultured at $37^{\circ} \mathrm{C}$ for $48 \mathrm{~h}$, fresh medium containing $400 \mu \mathrm{g} / \mathrm{ml}$ of $\mathrm{G} 418$ (active concentration) was added and mixtures of G418-resistant colonies appearing by $14 \mathrm{~d}$ were allowed to grow to confluence. Additional cell lines derived from single cell clones using terminal dilution in 96-well plates were also obtained. Because our ( $r$ )AAV was not purified, the calculated efficiency of transduction of $1-2 \%$ (data not shown) is a gross underestimate, because the ratio of defective to infectious virions has been estimated to be between 20:1 and 200:1 (16).

\section{DNA/RNA extraction and analysis}

After digestion of $10 \mu \mathrm{g}$ genomic DNA with HindIII and PstI, electrophoresis in $1 \%$ agarose gels, and transfer to nylon filters, hybridization was performed with FR cDNA $(1.1 \mathrm{~kb}), n e o^{\mathrm{R}}(2.4 \mathrm{~kb})$, and rff-DNA 
probes, which were radiolabeled (random hexanucleotide primer method) to a specific activity of $\sim 0.3 \mathrm{mCi} / \mu \mathrm{g}$ DNA. Membranes were washed under stringent conditions with $1.5 \mathrm{mM}$ sodium citrate $(\mathrm{pH}$ $7.0), / 15 \mathrm{mM} \mathrm{NaCl} / 0.1 \% \mathrm{SDS}$ at $65^{\circ} \mathrm{C}$, and autoradiographed at $-80^{\circ} \mathrm{C}$ (36). For Northern analysis, $10 \mu \mathrm{g}$ of RNA (40) was electrophoresed, transferred to nylon membranes, and hybridized with ${ }^{32} \mathrm{P}$-labeled FR cDNA, ${ }^{32} \mathrm{P}$-labeled $n e o^{\mathrm{R}}$, and ${ }^{32} \mathrm{P}$-labeled $\beta$-actin DNA (36). For singlestranded RNA probes, FR cDNA ( $1.1 \mathrm{~kb}$ ) was subcloned into the EcoRI site of pSPT18 followed by removal of the multiple cloning sites (HindIII to SacI) in the vector to form pSPT18-FR. For the sense singlestranded RNA probe, pSPT18-FR was linearized with PstI and transcribed by SP6 RNA polymerase; for the antisense single-stranded RNA probe, pSPT18-FR was linearized with AvaI and transcribed by T7 RNA polymerase according to the manufacturer's protocol. For singlestranded RNA probe hybridization, membranes were incubated in buffer ( $30 \mathrm{mM}$ sodium citrate ( $\mathrm{pH} \mathrm{7.0)/300} \mathrm{mM} \mathrm{NaCl} / 10 \mu \mathrm{g} / \mathrm{ml}$ ribonuclease A) at $22^{\circ} \mathrm{C}$ for $30 \mathrm{~min}$ before autoradiography and quantitation of autoradiograms using a densitometer (model 630; BioRad Laboratories, Richmond, CA)

\section{Quantitation of $\left[{ }^{3} \mathrm{H}\right]$ PteGlu binding to $F R$}

Studies on intact $\mathrm{HeLa}-\mathrm{IU} \mathrm{U}_{l}$ cells. After cells $\left(2-7 \times 10^{5}\right)$ were cultured in 24-well plates to $80 \%$ confluency, all subsequent experiments were conducted at $4^{\circ} \mathrm{C}$ using ice-cold buffers. Cells were sequentially washed four times ( $1 \mathrm{ml}$ PBS per wash cycle) to remove the high concentrations of folate extant in commercial media. To remove endogenous-bound folate from FRs on cell surfaces $(29,30)$, cells were then washed twice with $1 \mathrm{ml} 0.05 \mathrm{M}$ sodium acetate-acetic acid ( $\mathrm{pH} 4.5) / 0.15 \mathrm{M} \mathrm{NaCl}$ ( $30 \mathrm{~s}$ per wash), then washed twice with PBS. After $1 \mathrm{ml}$ of PBS was added to each well, 125 pmol $\left[{ }^{3} \mathrm{H}\right]$ PteGlu alone or together with 566 nmol unlabeled PteGlu (to obtain values for total and nonspecific radioligand binding, respectively) was added and the mixture was incubated for $2 \mathrm{~h}$. Cells were then washed four times with PBS to remove unbound radioligand. After verification of complete removal of unbound radioligand, $1 \mathrm{ml} 5 \mathrm{M} \mathrm{NaOH}$ was added, and the entire sample was analyzed for radioactivity, as described (30). In addition, two wells of each cell line were used to determine mean cell counts. Scatchard analysis was also carried out on intact untransduced, sense, and antisense cells, as described (41).

Studies on total FRs from solubilized cells. Total cellular $\left[{ }^{3} \mathrm{H}\right]-$ PteGlu binding to FRs was determined as follows: cells were washed with $10 \mathrm{ml}$ PBS, harvested with PBS/10 mM EDTA, and centrifuged at $1,000 \mathrm{~g}$ for $10 \mathrm{~min}$. The pellets were solubilized in $1 \mathrm{ml}$ PBS $/ 5 \mathrm{mM}$ EDTA/1\% Triton X-100/0.05\% Na azide, at $4^{\circ} \mathrm{C}$ overnight (30). To dissociate FR-bound endogenous folates (42), all samples were sequentially dialyzed (with dialysis buffer changes every $12 \mathrm{~h}$ ) against (a) 4 liters $50 \mathrm{mM} \mathrm{Na}$ acetate-acetic acid ( $\mathrm{pH} 4.5) / 0.05 \% \mathrm{Na}$ azide $/ 10 \mathrm{mM}$ EDTA/1\% Triton X-100 for $3 \mathrm{~d}$; (b) 4 liters $100 \mathrm{mM}$ potassium phosphate $(\mathrm{pH} 7.5) / 1 \%$ Triton $\mathrm{X}-100 / 0.05 \% \mathrm{Na}$ azide, for $1 \mathrm{~d}$; and $(c) 4$ liters $10 \mathrm{mM}$ potassium phosphate $(\mathrm{pH} 7.5) / 1 \%$ Triton $\mathrm{X}-100 / 0.05 \%$ $\mathrm{Na}$ azide, for $1 \mathrm{~d}$. After centrifugation $(30,000 \mathrm{~g}$ for $30 \mathrm{~min})$, the supernatant was saved for protein determination and $100 \mu \mathrm{l}$ was incubated with 44 pmol $\left[{ }^{3} \mathrm{H}\right.$ ] PteGlu for $45 \mathrm{~min}$ at $37^{\circ} \mathrm{C}$ before application over a calibrated $1 \times 10 \mathrm{~cm}$ Sephacryl S-200 gel filtration column (Spectrum Medical Industries, Houston, TX), which was equilibrated and eluted with $10 \mathrm{mM}$ potassium phosphate $(\mathrm{pH} \mathrm{7.5)/1 \%} \mathrm{Triton} \mathrm{X}$ $100 / 0.05 \% \mathrm{Na}$ azide at $22^{\circ} \mathrm{C}$. Fractions of $580 \mu \mathrm{l}$ were collected and counted for radioactivity. A similar protocol was used to analyze folate binding to tumor tissue from transplanted nude mice.

\section{Fluorescence-activated cell sorting analysis}

Mouse antiplacental FR IgG mAbs were prepared in our laboratory. ${ }^{4}$ Aliquots of washed $0.5 \times 10^{5}$ cells from each cell line were used for fluorescence-activated cell sorting (FACS) analysis. Cells in $50 \mu \mathrm{l}$ cold D-PBS were incubated with $6 \mu \mathrm{g}$ antiplacental FR mAb or $6 \mu \mathrm{g}$ of

4. Gullapalli, S., and A. C. Antony, unpublished data. normal mouse (nonimmune) IgG for $20 \mathrm{~min}$ at $4^{\circ} \mathrm{C}$. After sedimentation ( $1000 \mathrm{~g}$ for $10 \mathrm{~min}$ ) at $4^{\circ} \mathrm{C}$ and two washes ( $3 \mathrm{ml}$ ice-cold PBS per centrifuge wash cycle), samples were incubated with $5 \mu \mathrm{g}$ fluorescein isothiocyanate-conjugated goat anti-mouse IgG on ice for $20 \mathrm{~min}$. After two washes with ice-cold PBS, as described above, cells were resuspended in $200 \mu \mathrm{l}$ D-PBS and immediately analyzed on a FACScan (Becton Dickinson Immunocytometry Systems, San Jose, CA). Positive fluorescence was defined as that which was $99 \%$ higher than fluorescence obtained from duplicate samples stained with the nonimmune mouse IgG. The mean fluorescence intensity between anti-FR mAb and nonimmune IgG allowed for direct comparison of surface expression of FRs between sense and antisense cells.

\section{Cell proliferation in vitro and in vivo}

Cloning efficiency and colony size was determined as follows: 500 cells were plated on each of three $60 \times 15$-mm dishes with $3 \mathrm{ml}$ MEM containing $10 \% \mathrm{FCS}$ at $37^{\circ} \mathrm{C}$ in $5 \% \mathrm{CO}_{2} .1$ wk later, cells were fixed on the dishes and stained (Accustain; Wright-Giemsa; reference 5). The number and mean diameter of each colony (from one of three dishes randomly chosen) was determined under microscopic visualization as described (5) by measuring the widest diameter of each colony at perpendicular axes and dividing the result by 2 .

To determine the proliferation of each of the cell lines cultured in MEM containing $10 \%$ FCS, $10^{4}$ cells in triplicate were plated in either $60 \times 15-\mathrm{mm}$ plates (fed with $3 \mathrm{ml}$ media) or $100 \times 20$-mm plates (fed with $10 \mathrm{ml}$ media). For cells cultured in MEM containing $2 \%$ FCS, $10^{5}$ cells were plated in 24-well plates containing $2 \mathrm{ml}$ media. After various days in culture, cells were trypsinized and counted in a Coulter counter (6) and assayed for protein (43). As a routine, before cells were counted, they were visualized under light microscopy to ensure they were single cell suspensions.

The doubling time (44) was derived from the relationship:

$\log _{10} N=D \times \log _{10} 2$,

where $\mathrm{N}=$ final cell number, $\mathrm{N}_{\mathrm{x}}$ is divided by the original cell number, $\mathrm{N}_{0}$, or,

$\mathrm{N}=\mathrm{N}_{\mathrm{x}} / \mathrm{N}_{0}$,

and the number of doublings (D), is defined by the equation:

$D=\Delta t / D_{t}$,

where $\Delta t$ is the duration in culture and $D_{t}$ is the doubling time. Substituting for equations 2 and 3 in equation 1 , and using $\log _{10} 2=0.301$, the equation is:

$\log _{10} N_{x} / N_{0}=\Delta t / D_{t} \times 0.301$,

or,

$D_{t}=\Delta t \times 0.301 / \log _{10} N_{x} / N_{0}$,

or,

$D_{\mathrm{t}}=0.301 \times \Delta \mathrm{t} / \log _{10} \mathrm{~N}_{\mathrm{x}} / \mathrm{N}_{0}$.

For cell proliferation studies in vivo, $1.5 \times 10^{7}$ cells of each cell line were transplanted into 5-wk-old, 18-22-g, male, athymic nude mice (Harlan Sprague Dawley, Cumberland, IN) by subcutaneous injection (four mice/cell line). (All animal experiments were approved by the Institutional Review Board, Indiana University School of Medicine, Indianapolis, IN). After $1 \mathrm{wk}$, tumor dimensions were measured and mice were weighed every other day. Tumor weights and doubling times were calculated as described (45). After the mice were killed on day 25 after transplantation and tumors removed in toto, internal organs were examined for metastasis. One aliquot of each tumor (one from each of four mice for each cell-derived tumor) was embedded in paraffin, sectioned, stained (with hematoxylin-eosin), and evaluated histopathologically. Another aliquot of tumor tissue was homogenized with $2 \mathrm{vol}(\mathrm{vol} / \mathrm{wt}) 10 \mathrm{mM}$ potassium phosphate, $\mathrm{pH} 7.5$, using a Dounce 
homogenizer. After two centrifuge wash cycles $\left(30,000 \mathrm{~g}\right.$ at $4^{\circ} \mathrm{C}$ for 30 min), membrane pellets were solubilized, dialyzed, and analyzed for folate binding, as described above.

Formal analysis of a relationship between cell proliferation and FR expression

A total of 36 randomly picked, single cell-derived clones from the cohorts of untransduced and transduced cells ( 6 from untransduced cells, 15 from sense cells, and 15 from antisense cells) were used to determine if there was a relationship between cell proliferation and FR expression. Aliquots of $2 \times 10^{5}$ cells (in triplicate) from each clone were plated in $100 \times 20-\mathrm{mm}$ plates and fed with $10 \mathrm{ml}$ MEM containing $10 \%$ FCS. After $7 \mathrm{~d}$ in culture, the cells were harvested and counted, and total cellular $\left[{ }^{3} \mathrm{H}\right]$ PteGlu binding to solubilized FRs was also determined, as described above.

Other studies. The concentrations of unlabeled PteGlu, DNA, and RNA were estimated by spectrophotometry $(36,46)$. Specific $\left[{ }^{3} \mathrm{H}\right]-$ PteGlu binding to intact cells was defined as the difference between total and nonspecific $\left[{ }^{3} \mathrm{H}\right] \mathrm{PteGlu}$ binding (42). Because nonspecific radioligand binding to FR cDNA-transduced and untransduced $\mathrm{HeLa}$ $\mathrm{IU}_{1}$ cells was $<5 \%$ and recovery of applied radioactivity after gel filtration was consistently $\sim 90 \%$, the peak of radioligand-bound hydrophobic FRs among different cells expressed as a function of cell number and protein was directly comparable among cohorts of cells. Because FRs have a 1:1 molar stoichiometry for folate binding $(4,47)$, the moles of folate bound per milligram of protein represented the moles of FR per milligram of protein. Statistical analysis (see Table I and Figs. 5-7) was carried out using the Student's $t$ test. The data on the relationship between cell proliferation and FR expression for all three cohorts of cells were analyzed by linear regression, and Pearson's correlation coefficient was determined as described (48).

\section{Results}

Integration of ( $r) A A V$ containing sense/antisense FR cDNAs in $\mathrm{HeLa}-\mathrm{IU} \mathrm{U}_{1}$ cells. After transduction and selection of G418resistant cells, integration of (r)AAV into genomic DNA was analyzed by Southern blots. When DNA from untransduced cells, sense FR cDNA-transduced cells (referred to as sense cells), and antisense FR cDNA-transduced cells (referred to as antisense cells) was hybridized with ${ }^{32} \mathrm{P}$-labeled $n e o^{\mathrm{R}}$ DNA (Fig. $2 \mathrm{~A}$ ), signals $>23 \mathrm{~kb}$ were observed for undigested DNA from both sense and antisense cells; no signals were noted in the untransduced cells. After digestion with PstI and hybridization with ${ }^{32} \mathrm{P}$-labeled FR cDNA (Fig. 2 B), sense cells contained an additional 0.9-kb band, whereas antisense cells contained a 2.1-kb band that overlapped with one among several endogenous FR gene signals (49). These data signified that both $n e o^{\mathrm{R}}$ and FR cDNA integrated into genomic DNA.

To analyze the pattern of integration of ( $r$ AAV, the following studies were performed: $(a)$ Based on the restriction map of (r)AAV (Fig. $3 G$ ), HindIII has one cleavage site in pBARS and pAnti-BARS. Thus, if (r)AAV integrated site-specifically, after digestion with HindIII, we ought to have obtained only one additional hybridization signal for the FR gene, and a single signal for $n e o^{\mathrm{R}}$ in transduced cells when ${ }^{32} \mathrm{P}$-labeled FR cDNA or ${ }^{32} \mathrm{P}$-labeled $n e o^{\mathrm{R}} \mathrm{DNA}$ were used. However, Southern analysis indicated that when compared with untransduced cells, genomic DNA from both sense and antisense cells contained no additional FR signals; no signals were also observed with the neo ${ }^{\mathrm{R}}$ DNA probe (data not shown). One possible explanation for these results could be that unique hybridization signals did in fact exist, but because of random integration of our (r)AAV into the genome of several transduced cells, such signals would

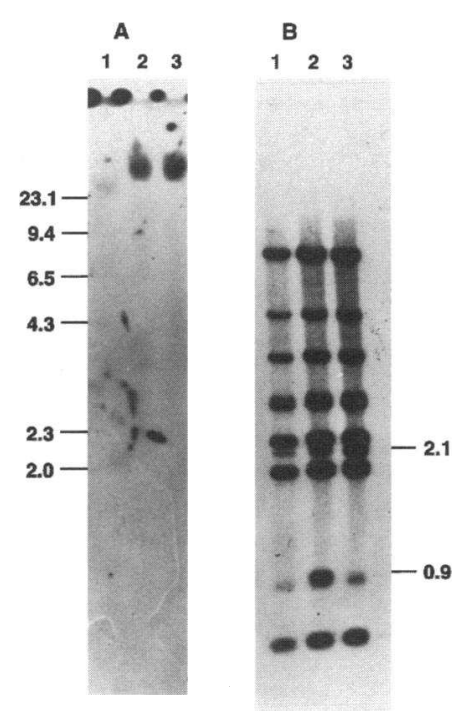

Figure 2. Southern analysis of genomic DNA from untransduced, sense FR cDNA-transduced, and antisense FR cDNA-transduced HeLa-IU, cells. Undigested DNA was hybridized with $(A){ }^{32} \mathrm{P}-\mathrm{neo}^{\mathrm{R}}$ DNA or $(B)$ PstI-digested DNA hybridized with ${ }^{32} \mathrm{P}-\mathrm{FR}$ cDNA. Lane 1 , DNA from untransduced cells; lane 2, DNA from sense FR cDNA-transduced cells; lane 3, DNA from antisense FR cDNA-transduced cells. The migration of known $\mathbf{M}_{\mathrm{r}}$ markers are shown on the left, and the fragment size of the introduced genes are indicated on the right.

be significantly diluted and therefore not be visualized on Southern blots. To analyze this possibility, we obtained single cellderived clones from transduced sense and antisense cells. Southern analysis of genomic DNA from several clones, each individually restricted with HindIII and probed with ${ }^{32} \mathrm{P}$-labeled FR cDNA (Fig. $3 A$ ) revealed additional different sized hybridization signals that were distinct from the endogenous FR gene signals. In addition, with ${ }^{32} \mathrm{P}$-labeled neo ${ }^{\mathrm{R}} \mathrm{DNA}$, distinct signals appeared among different single cell-derived clones (Fig. 3 $B$ ), consistent with random integration of transduced (r)AAV.

(b) Based on restriction maps of ( $r$ )AAV, PstI has five sites for cleavage in pBARS and pAnti-BARS; only one site for cleavage was not common (Fig. $3 G$ ). Thus, if integration of (r)AAV was site specific, after cleavage with PstI and use of ${ }^{32} \mathrm{P}$-labeled $n e o^{\mathrm{R}}$, there would only be three signals for either sense cells ( 0.9 and $1.2 \mathrm{~kb}$, and another of unknown size) or antisense cells ( 0.9 and $2.1 \mathrm{~kb}$, and another of unknown size). However, with ${ }^{32} \mathrm{P}$-labeled neo ${ }^{\mathrm{R}}$ DNA (Fig. $3 C$ ), we obtained only two clear bands that in sense cells were 0.9 and $1.2 \mathrm{~kb}$ and in antisense cells were 0.9 and $2.1 \mathrm{~kb}$. Thus, in both sense and antisense cells, the missing signal was likely related to that portion of the $n e o^{\mathrm{R}}$ gene that was between the integrated virion DNA and the next expected PstI site in the genome. Again, the lack of detection of the flanking sequence could be a function of dilution of each of the flanking DNA sequences from individual transduced cells, which would not be the same size under conditions of random integration of (r) AAV (i.e., these signals would be too weak to be detected). In fact, when films were exposed for 2 and $3 \mathrm{~d}$ (Fig. 3, $D$ and $E$ ), there were several additional weak bands visualized for both sense and antisense cells when compared with untransduced cells. The sizes of these signals were 1.5 to $4.5 \mathrm{~kb}$, suggesting that our (r) AAV integrated randomly into $\mathrm{HeLa}-\mathrm{IU}_{1}$ cells.

c) wt-AAV integrates site specifically into chromosome 19 , and a 300-bp right flanking DNA fragment (rff-DNA) corresponding to the region of integration has been cloned out of Detroit 6 cells (18). rff-DNA contains a PstI site; thus, when genomic DNA from untransduced cells was analyzed after PstI digestion, two distinct hybridization signals should have been obtained. If the locus of integration of (r)AAV was within the region adjacent to rff-DNA, we expected a disruption of this 

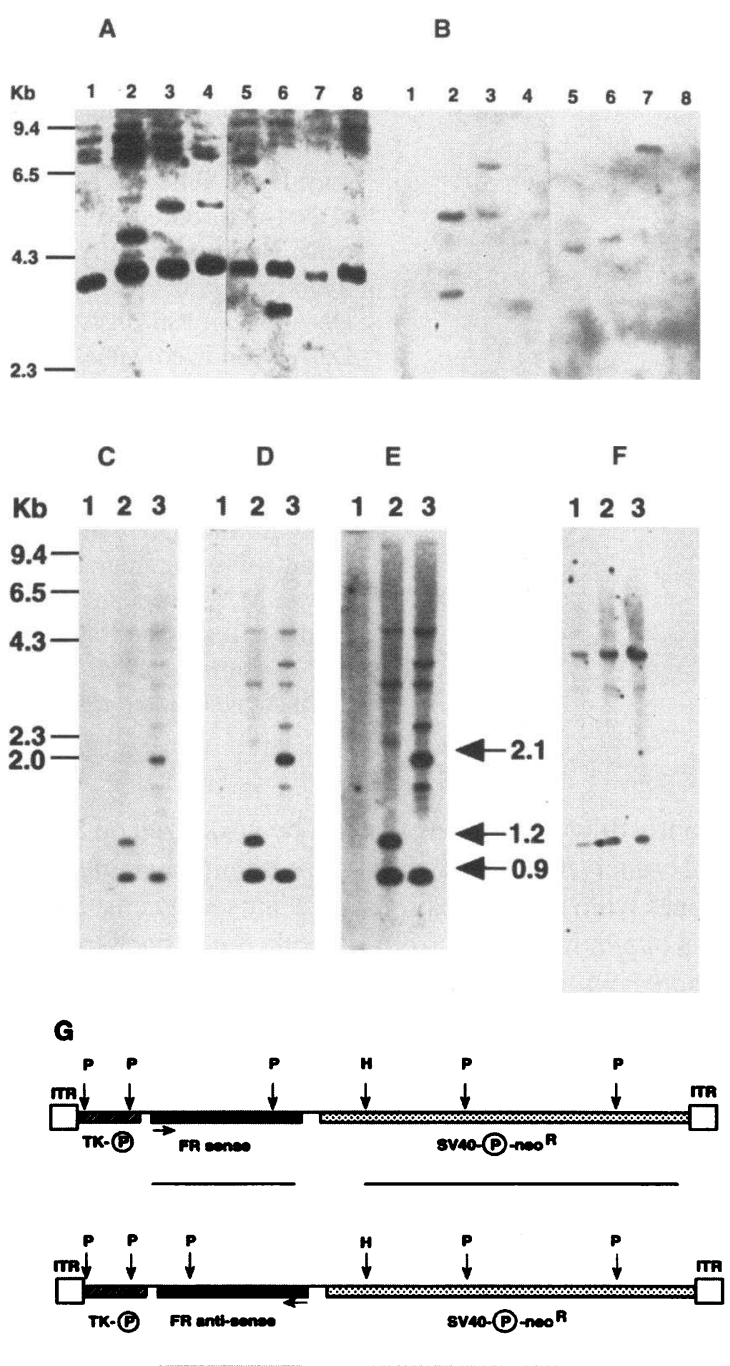

Figure 3. Pattern of ( $\mathrm{r}) \mathrm{AAV}$ integration. $(A$ and $B$ ) DNA from single cell-derived clones was digested with HindIII and hybridized with $(A)$ ${ }^{32} \mathrm{P}$-FR cDNA and $(B)$ neo ${ }^{\mathrm{R}} \mathrm{DNA}$. Lane 1 and lane 8 , untransduced cells; lanes $2-4$, sense cells; and lanes $5-7$, antisense cells. $(C-F)$ DNA from untransduced cells (lane 1), sense cells (lane 2), and antisense cells (lane 3) was digested with PstI, hybridized with ${ }^{32} \mathrm{P}_{-n e o^{R}}$ DNA, and exposed to Kodak x-Omat-RP film for $(C) 1 \mathrm{~d},(D) 2 \mathrm{~d}$, and $(E) 3 \mathrm{~d}$. ( $F)$ After stripping, the membrane was rehybridized with ${ }^{32}$ P-rff-DNA. $(G)$ Restriction map of RVS-BARS and RVS-AntiBARS provirus (between ITRs) and the location of 1.1-kb FR cDNA probe and $2.4 \mathrm{~kb}$ neo ${ }^{\mathrm{R}}$ DNA probe (straight lines below the map). $\mathrm{H}$, HindIII; P, PstI.

region to manifest itself as a signal that was larger or smaller than signals from untransduced cells. The results on blots probed with ${ }^{32} \mathrm{P}$-labeled rff-DNA revealed only two signals in PstI-digested DNA from untransduced, sense, and antisense cells (Fig. $3 F$ ). This suggested that $(a)$ there was only one DNA region corresponding to rff-DNA in our cells, consistent with karyotypic analysis of $\mathrm{HeLa}-\mathrm{IU}_{1}$ cells that identified only two copies of chromosome 19; and $(b)$ this region was not disrupted during integration of $(\mathrm{r}) \mathrm{AAV}$, consistent with the conclusion that the locations of integration of ( $r$ ) AAV and wtAAV were not the same. In support of this premise, when Southern blots in Fig. 3, $A$ and $B$, were re-probed with ${ }^{32} \mathrm{P}-$

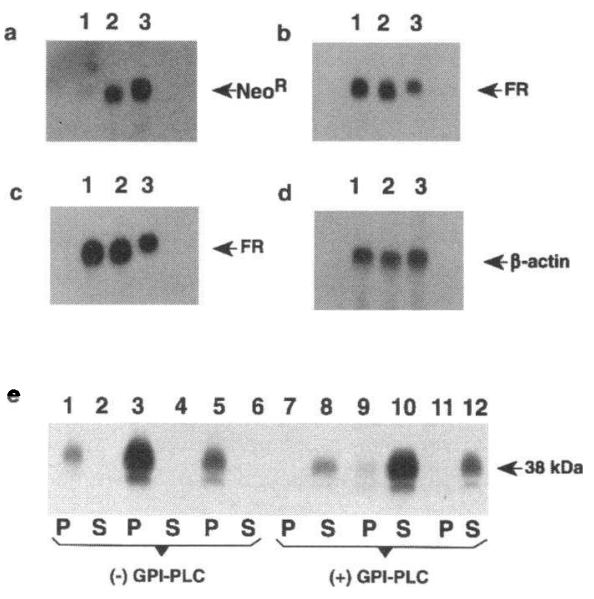

Figure 4. Northern blot analysis of FR expression and analysis of GPI anchoring of FRs in untransduced and transduced cells. $(a-d)$ RNA from untransduced (lane 1 ), sense FR cDNA-transduced (lane 2), and antisense FR cDNA-transduced (lane 3) HeLa-IU, cells was hybridized with ${ }^{32}$ P-labeled probes as follows: $(a)$ neo ${ }^{\mathrm{R}}$ DNA, $(b)$ FR DNA, $(c)$ single-stranded antisense FR RNA, or $(d) \beta$-actin DNA probes. $10 \mu \mathrm{g}$ total RNA from each cell line was separated on $1 \%$ agarose- $6 \%$ formaldehyde gel, transferred to nylon membranes, and probed with ${ }^{32} \mathrm{P}$-DNA or ${ }^{32} \mathrm{P}$-RNA. (e) $\left[{ }^{35} \mathrm{~S}\right]$ Cysteine-labeled total cellular proteins $(120 \mu \mathrm{g})$ from untransduced, sense, and antisense cells that sequestered into the cloud point of Triton X-114 by virtue of their hydrophobicity were incubated without (lanes 1-6) or with (lanes 7-12) GPI-PLC. After temperature-induced phase separation, the resulting aqueous phase containing GPI-PLC-generated hydrophilic ${ }^{35} \mathrm{~S}$-labeled FRs and micellar phase containing GPI-PLC-resistant ${ }^{35} \mathrm{~S}$-labeled FRs were specifically immunoprecipitated with anti-PFR antiserum and IgGsorb, and the samples were analyzed by SDS-PAGE and fluorography. P, pellet (detergent-rich phase); $\mathrm{S}$, supernatant (detergent-poor phase).

labeled rff-DNA, each single cell-derived clone had a single $\sim 6.5-\mathrm{kb}$ signal corresponding to the rff-DNA as noted with untransduced cells (data not shown). Thus, the rff-DNA-related DNA region was not disrupted in single cell-derived clones. Together, these data strongly suggested that AAV ITRs alone could not direct site-specific integration of ( $r$ AAV.

Modulation of FR expression at the mRNA level in transduced cells. Northern blot analysis was carried out to determine if integration was followed by transcription of exogenously introduced genes (Fig. 4, $a-d$ ). RNA from untransduced cells had the expected FR signal but no neo ${ }^{\mathrm{R}}$ signal, whereas sense and antisense cells had both $n e o^{\mathrm{R}}$ and FR mRNA signals. When relative intensities of the FR mRNA signals from untransduced cells were quantitatively compared with corresponding $\beta$-actin signals by densitometry, the intensity of the FR mRNA signal as a percentage of the $\beta$-actin mRNA signal was $108 \%$, whereas sense cells gave a FR/ $\beta$-actin ratio of $129 \%$ and antisense cells gave a ratio of $52 \%$. When normalized to the value for untransduced cells, sense cells had a $19 \%$ increase of net FR mRNA, whereas the antisense cells reduced net FR mRNA by $48 \%$. Because the probe used for evaluation of FR mRNA was double-stranded FR cDNA, the signal obtained from antisense cells could be a result of hybridization of the antisense transcribed mRNA strand with the sense strand of FR cDNA. To determine the endogenous level of sense FR mRNA in these cells, the blots were rehybridized with single-stranded sense and antisense FR RNA probes. The antisense FR RNA probe 
Table I. Results of $\left[^{3} \mathrm{H}\right]$ PteGlu-binding Assays to Total Solubilized FRs and Cell Surface FRs as well as Quantitation of FRs by FACS Analysis on Untransduced, Sense FR cDNA-, and Antisense FR cDNA-Transduced HeLa-IU ${ }_{1}$ Cells

\begin{tabular}{lccc}
\hline \multicolumn{1}{c}{ Cell line } & $\begin{array}{c}\text { Total cell } \\
\text { FR binding } \\
\text { (pmol/mg) }\end{array}$ & $\begin{array}{c}\text { Cell surface FR } \\
\text { binding } \\
\text { (fmol/10 cells) }\end{array}$ & $\begin{array}{c}\text { FACS analysis } \\
\text { (mean surface } \\
\text { fluorescence) }\end{array}$ \\
\hline Untransduced cells & 31.0 & $37.6 \pm 0.7$ SEM & $194 \pm 12$ SEM \\
$\begin{array}{c}\text { Sense FR cDNA- } \\
\text { transduced cells }\end{array}$ & 57.0 & $\begin{array}{c}61.3 \pm 3.6 \mathrm{SEM} \\
(163 \%)^{\ddagger}\end{array}$ & $\begin{array}{c}224 \pm 11 \mathrm{SEM} \\
(116 \%)^{\S}\end{array}$ \\
$\begin{array}{c}\text { Antisense FR cDNA- } \\
\text { transduced cells }\end{array}$ & 36.0 & $\begin{array}{c}31.4 \pm 0.6 \mathrm{SEM} \\
(84 \%)^{\ddagger}\end{array}$ & $\begin{array}{c}141 \pm 12 \mathrm{SEM} \\
(73 \%)^{\S}\end{array}$ \\
\hline
\end{tabular}

* Mean fluorescence of positive events calculated on a linear scale.

‡ Percentage of control (FR-specific fluorescence) in untransduced cells.

${ }^{8}$ Percentage of control $\left(\left[{ }^{3} \mathrm{H}\right]\right.$ PteGlu-binding) in untransduced cells.

(Fig. $4 c$ ) identified that endogenous FR expression in antisense cells was comparably reduced to that revealed with the doublestranded FR cDNA probe (Fig. $4 b$ ). However, despite use of the single-stranded sense FR RNA probe, RNase protection, and primer extension assays, we did not detect antisense RNA (data not shown). This suggested that expressed antisense FR mRNA was completely quenched by constitutively overexpressed endogenous sense FR mRNA, likely leading to rapid degradation of sense-antisense mRNA hybrids (50-52). Nevertheless, when taken together, these data supported the conclusion that transcribed antisense FR cDNA was functional in suppressing the endogenous FR gene expression at the transcriptional level, while transcribed sense FR cDNA augmented net sense FR mRNA expression.

Analysis of FRs in untransduced, sense, and antisense HeLa-IU ${ }_{I}$ cells. To determine whether the FRs in these cells were GPI anchored, the strategy used was to first biosynthetically label all cellular proteins (including FRs) with $\left[{ }^{35} \mathrm{~S}\right]-$ cysteine and then to treat the samples with GPI-PLC in the presence of nonspecific proteinase and FR-directed metalloprotease inhibitors. ${ }^{3}$ We reasoned that if ${ }^{35} \mathrm{~S}$-labeled FRs were GPI anchored, they would initially sequester into the micellar phase at the cloud point of Triton X-114. However, after incubation with GPI-PLC, these species would be released into the aqueous phase after temperature-induced phase separation. This could be monitored by determining the extent of immunoprecipitation of ${ }^{35} \mathrm{~S}$-labeled FRs from the aqueous and micellar phases using anti-PFR antiserum. Thus, if some ${ }^{35} \mathrm{~S}$-labeled FRs were not GPI anchored, they would continue to remain within the micellar phase even after incubation with GPI-PLC. As shown in Fig. $4 e$, before GPI-PLC, ${ }^{35} \mathrm{~S}$-labeled FRs entirely sequestered in the micellar phase (lanes 1,3 , and 5), consistent with their intrinsic hydrophobic nature. However, following GPI-PLC, all of the ${ }^{35} \mathrm{~S}$-labeled FRs from untransduced and antisense cells and $94 \%$ from sense cells were released into the aqueous phase as hydrophilic species (lanes 8,10 , and 12). These data were consistent with the conclusion that the FRs in these cells were GPI anchored. In addition, as verified by folate-binding studies in vitro and in vivo (Table I and Figs. 7 and 8), the total cellular ${ }^{35} \mathrm{~S}$-labeled FRs in sense cells were significantly increased when compared with antisense cells, which contained more ${ }^{35} \mathrm{~S}$-labeled FRs than untransduced cells.

The results of specific $\left[{ }^{3} \mathrm{H}\right]$ PteGlu-binding to the cell sur- face membrane-associated FRs and total cellular FRs are shown in Table I. Sense cells had an increase in cell surface folate binding of $63 \%$, whereas antisense cells had a decreased cell surface folate binding of $16 \%$, when each was compared with untransduced cells. However, because sense and antisense cells were also internal controls for one another, the twofold difference in the ratio of the cell surface $\left[{ }^{3} \mathrm{H}\right]$ PteGlu binding in sense versus antisense cells was much more obvious. Furthermore, $\left[{ }^{3} \mathrm{H}\right]$ PteGlu binding to total FRs from solubilized cells revealed a proportional increase in sense cells when compared with untransduced and antisense cells. However, the slight increase of total FR content in antisense cells (compared with untransduced cells) was probably related to posttranslational regulatory changes (see Discussion). When the ratio of total FRs between sense and antisense cells was determined, the 1.6fold difference was also comparable and consistent with data on FR expression on cell surfaces. There were only minor differences in the dissociation constant of FRs in intact untransduced, sense, and antisense cells $\left(K_{\mathrm{d}}=0.85 \mathrm{nM}, 0.35 \mathrm{nM}\right.$, and 1.35 $\mathrm{nM}$, respectively). Thus, changes in folate binding capacity in various cells likely reflected true differences in FR expression.

To verify further that changes in PteGlu binding to FRs on transduced cells was not the result of an alteration in affinity of FRs, FR expression was quantitated by FACS using an antihuman placental FR MAb. When compared with untransduced cells (Table I), sense cells had increased expression of FRs (mean fluorescence intensity of $116 \%$ ), while antisense cells had decreased FR expression (mean fluorescence intensity of $73 \%$ ). When the ratio of mean surface fluorescence between sense and antisense cells was compared directly, there was a 1.6-fold increase in FR expression in sense cells, which was comparable with the data on folate binding to FRs.

Functional consequences of FR expression on cell proliferation in vitro and in vivo. The quantity of FRs expressed is inversely regulated by the extra- and intracellular folate concentrations (11). Therefore, to isolate and resolve the independent effects of FRs on cell proliferation, we determined the doubling time of sense and antisense cells under conditions where the potential regulatory variable of extra- and intracellular folate content on FRs was eliminated. This was achieved using suprapharmacologic extracellular folate concentrations $(2.3 \mu \mathrm{M}$ folic acid) in the growth medium, which ensured passive diffusion of folate into cells independent of FR expression (53).

When 500 cells were plated and the colonies enumerated 1 wk later, untransduced, sense, and antisense cells had 172 \pm 13 , $184 \pm 14$, and $189 \pm 9$ colonies/dish, respectively (Fig. 5). Thus, the cloning efficiency, and therefore the viability of each of the cell lines, was not significantly different from one another, a fact that is importance to the interpretation of results on the doubling time of these cells (see below). The mean diameters of colonies from untransduced, sense, and antisense cells were $0.519 \pm 0.16 \mathrm{~mm}, 0.393 \pm 0.108 \mathrm{~mm}$, and $0.524 \pm 0.158 \mathrm{~mm}$, respectively. Thus, sense cell colonies were significantly smaller $(P<0.001)$ when compared with untransduced or antisense cells, which were similar to one another.

There was apparently no major difference in cell proliferation when the transduced cell lines were propagated in MEM with $10 \%$ FCS for periods of $<3 \mathrm{~d}$. However, when the time of cell passage in culture was extended beyond $6 \mathrm{~d}$ (Fig. $6 \mathrm{~A}$ ) or the concentration of FCS in MEM was decreased from 10 to $2 \%$ (Fig. $6 \mathrm{~B}$ ), sense cells proliferated more slowly ( $P$ $<0.01$ ) when compared with either untransduced cells or anti- 


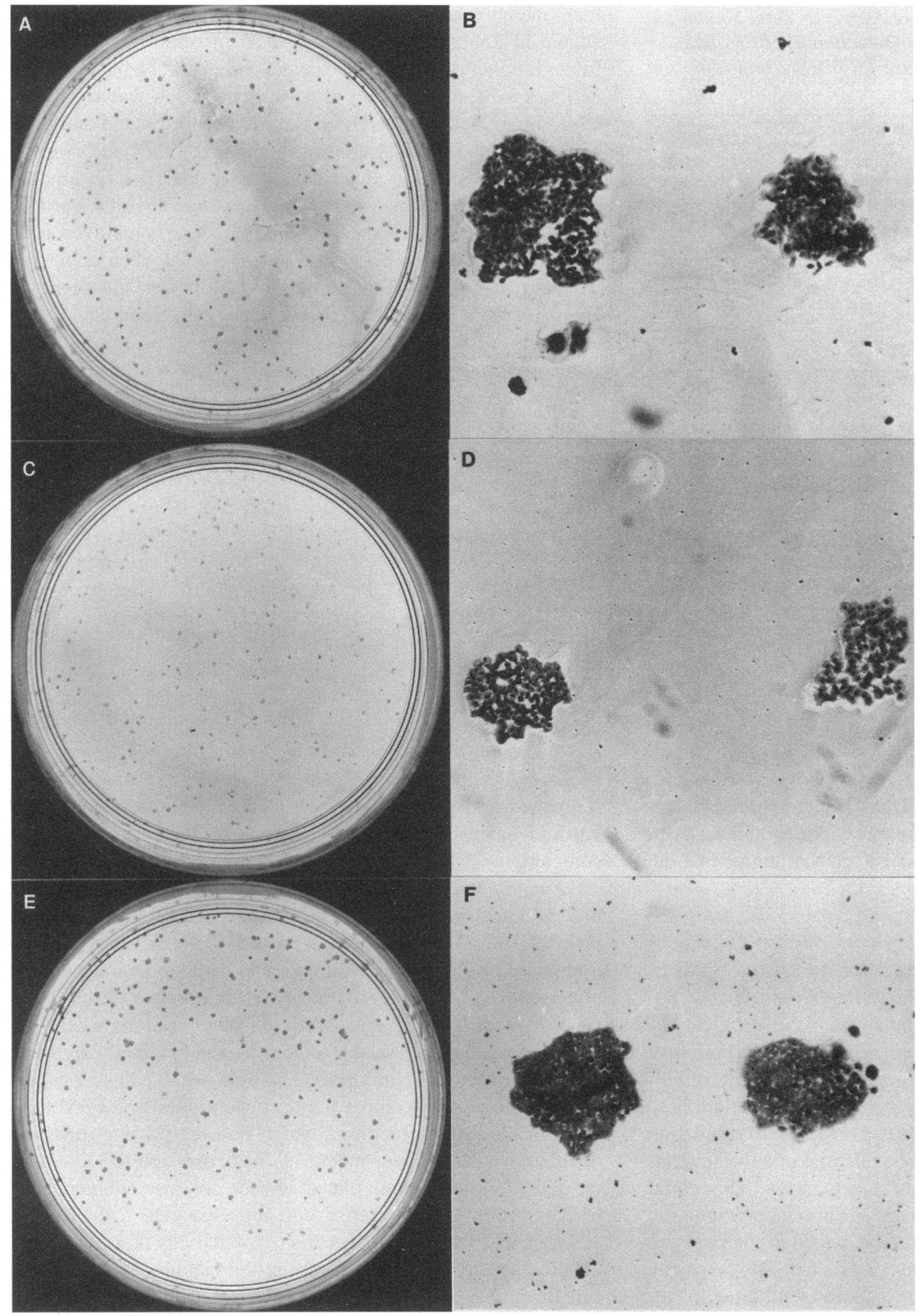

Figure 5. Cloning efficiency, colony size, and light microscopic analysis of $(A$ and $B)$ untransduced, $(C$ and $D)$ sense FR cDNA-transduced, and $(E$ and $F$ ) antisense FR cDNA-transduced cells. A total of 500 cells from each cell line were plated, and colony number and size were enumerated $1 \mathrm{wk}$ later as described in Methods. The original microscopic magnification for the panels on the right was $\times 10$. sense cells, which had similar proliferative rates to one another. Cell counts per dish were also verified by measurement of the total protein content per dish. On day 6 , the protein content of sense cells was lowest (Fig. $6 \mathrm{~A}$, inset) when compared with either antisense cells or untransduced cells $(P<0.01)$, indicating good correlation of cell numbers per dish with protein content per dish. The cell doubling time for each cell line in 10 and 2\% FCS was as follows: sense cells, 20.9 and $24.3 \mathrm{~h}$, respectively; untransduced cells, 19.9 and $22.2 \mathrm{~h}$, respectively; and antisense cells, 19.7 and $22.7 \mathrm{~h}$, respectively. Thus, when compared with untransduced and antisense cells, the doubling time of sense cells was prolonged by 1 and $2 \mathrm{~h}$ in 10 and $2 \%$ FCS, respectively.

One explanation for alteration in the proliferation of sense cells could be insertional mutagenesis during random integration of ( $r$ )AAV into HeLa-IU ${ }_{1}$ cells. This could be ruled out if single cell-derived clones from sense and antisense cells behaved similar to mixtures of transduced cells. When three single cell-derived clones were randomly chosen and analyzed for total folate binding capacity, all three sense cell lines exhibited a twofold increase in radioligand binding when compared with three antisense cell lines (data not shown). When compared 

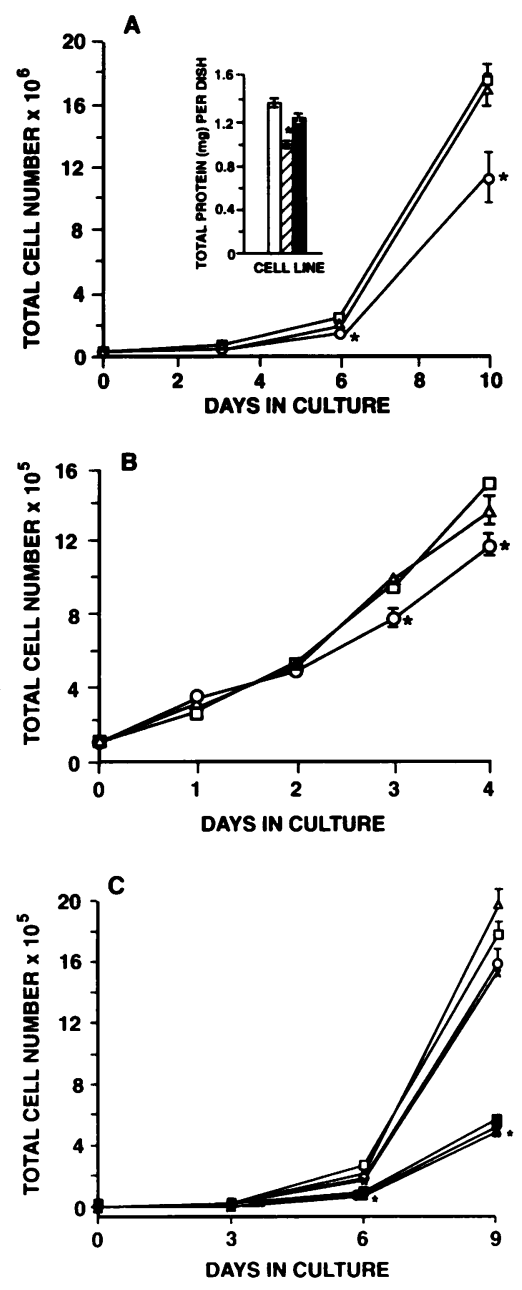

with untransduced cells, all three single cell-derived clones from sense cells had comparably slower rates of proliferation, while the three single cell-derived clones from antisense cells were similar to the untransduced cells (Fig. $6 C$ ). Thus, insertional mutation was an unlikely explanation for altered proliferation of sense cells.

To verify that in vitro data were not simply a unique function of cell culture conditions, the same number of randomly chosen, single cell clone-derived cells from each cohort were transplanted into nude mice ( 4 mice/cell line). After $1 \mathrm{wk}$, all mice exhibited single visible tumors. The sizes of the antisense cellderived tumors were similar to those from untransduced cellderived tumors throughout the period of analysis (Fig. 7). From day 11, however, when compared with the tumors derived from antisense cells, the tumors from sense cells were smaller ( $P$ $<0.01$ ). In addition, antisense cell- and untransduced cellderived tumors exhibited a tumor doubling time of $96.0 \mathrm{~h}$, whereas this value was $225.6 \mathrm{~h}$ in sense cell-derived tumors. The pictures (Fig. 7, right) are of representative mice on day 25 after transplantation with various cells indicated. The small tumor masses derived from sense cells clearly contrast with the larger tumors from antisense and untransduced cells. Histopathologic analysis revealed no gross cellular changes in tumors from all three cell lines, and there was no evidence of remote or recent hemorrhage within tumors (which could account for a greater tumor volume during external tumor measurements in vivo). In addition, examination of major internal organs (lungs, heart, liver, spleen, kidney, and intestines ) revealed no metastases that could account for reduced tumor cell mass at the primary injection site. Therefore, the increase in tumor volume and weight in untransduced and antisense cells when compared with sense cells was a result of a true increase in cells within the tumors. Thus, the prolonged cell doubling time identified in vitro in sense cells also led to a 2.4 -fold increase in tumor doubling time in vivo when compared with antisense and untransduced cell-derived tumors.

To verify that the transplanted cells continued to express FRs, the folate-binding capacity of FRs solubilized out of tumor tissues was determined. On day 25 , folate-binding capacity of sense, antisense, and untransduced cell-derived tumor tissue was $83.10 \pm 18.44,40.46 \pm 14.85$, and $13.87 \pm 2.66 \mathrm{pmol} / \mathrm{mg}$ protein, respectively. The difference between sense versus untransduced or antisense cell-derived tissues was significant $(P$ $<0.01$ and $P<0.05$, respectively). The results of antisense cell-derived tissues compared with untransduced cells was also significant $(P<0.05)$, which together with the twofold increase in FRs in sense versus antisense cells was comparable with that determined in vitro (Table I and Fig. 4, $e$ ).

Formal analysis of the relationship between cell proliferation and FR expression. A total of 36 cell lines derived from single cell clones ( 6 from untransduced cells, 15 from sense cells, and 15 from antisense cells) were used to test the hypothesis that there was an inverse relationship between cell proliferation and FR expression (Fig. 8). Not unexpectedly, all six untransduced cell clones exhibited comparable cell proliferation and FR expression $(P=\mathrm{NS})$. However, when the data points from sense FR cDNA- and antisense FR cDNA-transduced cells were combined, there was a highly significant inverse relationship between cell proliferation and FR expression $(r$ $=0.90, P<0.001, n=30$ ). When the data points from sense cells were combined with those from untransduced cells, the correlation coefficient also indicated a significant value ( $r$ $=0.82, P<0.001, n=21$ ); even with the data comparing antisense and untransduced cells, an $r$ value of $0.52(P<0.05$, $n=21$ ) was obtained. Finally, when data from all 36 cell lines were combined, the overall correlation coefficient value was still highly significant $(r=0.85, P<0.001)$. Thus, when viewed from several angles, these data consistently led to the unambiguous conclusion that there was an inverse relationship between FR expression and cell proliferation in these cells.

\section{Discussion}

Integration of $(r) A A V$. Since our ( $r$ AAV only retained ITRs of wt-AAV, we determined if they would direct site-specific integration. The results suggested random integration of (r) AAV into the genome of HeLa-IU $\mathrm{U}_{1}$ cells at the molecular level based on gene mapping (by Southern analysis). Although chromosome-specific integration implies a region in genomic DNA (consisting of several kilobases) wherein AAV can dock into one of several available sites $(19,20)$, signals generated by ${ }^{32} \mathrm{P}$-labeled rff-DNA suggested that docking sites for integration of ( $r$ AAV were not the same as wt-AAV. A trivial explanation for random integration (related to lack of chromosome 19 in our cells) was ruled out by results of hybridization with chromosome 19-specific rff-DNA probe and karyotype analysis. Thus, compared with earlier reports supporting site-specific integration of wt-AAV (17-20), our data suggested that ITRs 


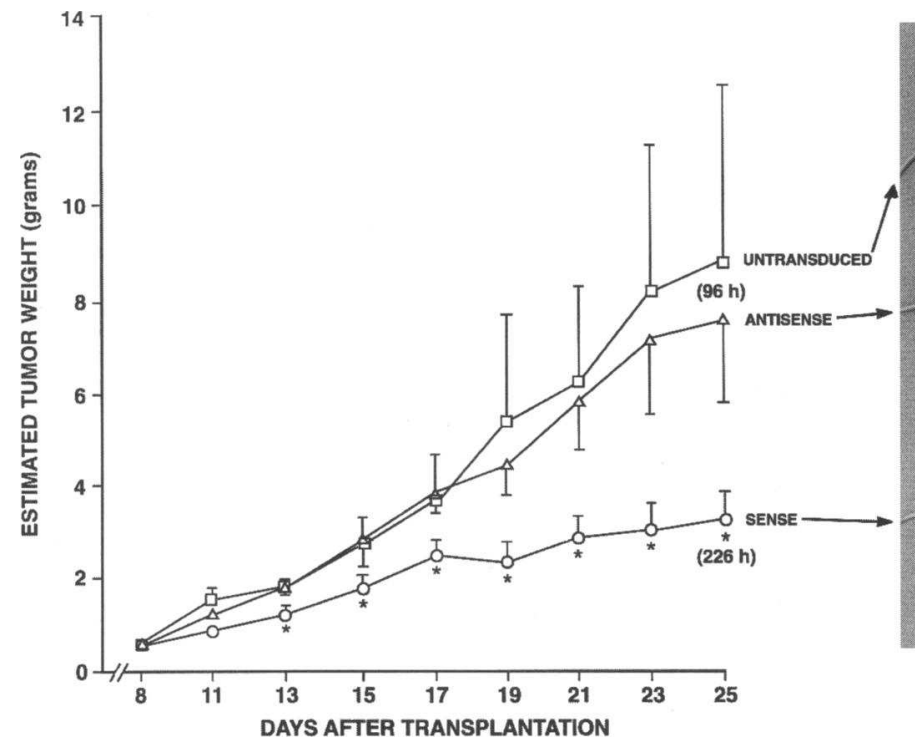

alone are insufficient to direct site-specific integration of (r) AAV in HeLa-IU ${ }_{1}$ cells. This could be because there are some unique DNA sequences in wt-AAV that are required for site-specific integration of AAV. Therefore, use of several combinations of ( $r) A A V$, which retain various structural or functional DNA sequences of the wt-AAV genome, are necessary to pursue this issue. Another possibility to explain these differences is related to the number of passages of cell lines after transduction. In earlier studies (18-21), cell lines were cultured for a long time (measured in years) after transduction with AAV before analysis for the pattern of integration; in contrast, we analyzed our G-418-resistant clones less than 10 mo after transduction, and in some experiments, the analysis was carried out in $2 \mathrm{mo}$. Thus, it is possible that over long periods in culture, some cell clones containing random integrated virions were lost, leading to a selection bias to explain those observations.

Expression and regulation of FRs. Several lines of evidence allowed for a direct comparison of the effects of sense and antisense FR cDNA transduction in HeLa-IU $\mathrm{I}_{1}$ cells: (i) The HeLa-IU $\mathrm{I}_{1}$ cells used for transduction were clonally derived. (ii)

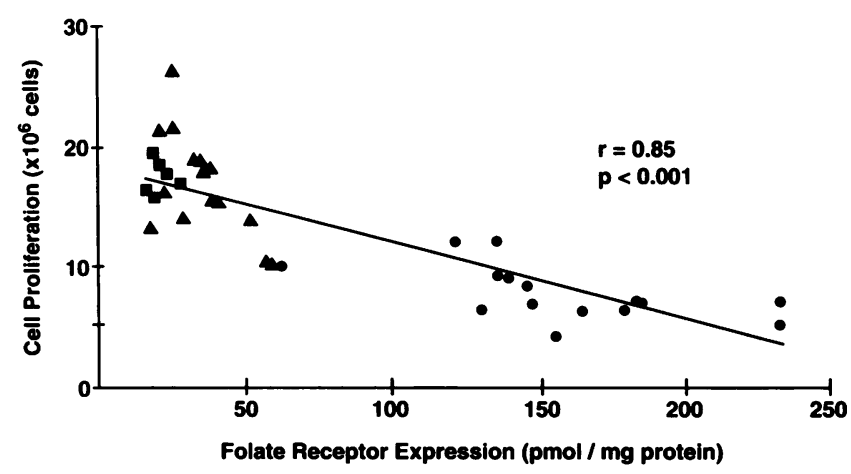

Figure 8. Determination of the relationship between cell proliferation and FR expression. A total of 36 randomly isolated, single cell clonederived cell lines, 15 from sense FR cDNA-transduced cells $(\bullet), 15$ from antisense FR cDNA-transduced cells $(\Delta)$, and 6 from untransduced control cells ( $\boldsymbol{\square})$ were analyzed for cell proliferation and FR expression, as described in Methods.
Figure 7. (Left) Proliferation of sense FR CDNA - and antisense FR cDNA-transduced and untransduced HeLa-IU $\mathrm{I}_{1}$ cells transplanted in vivo in nude mice. 1.5 $\times 10^{7}$ cells of each cell line were transplanted and tumor volumes were estimated as a function of time after transplantation. Asterisks indicate $P<0.01$ for sense FR cDNA-transduced cells when compared with antisense FR cDNA and untransduced cells. The tumor doubling times are indicated in parentheses. Each data point represents the mean \pm SD. (Right) Tumors in representative mice on day 25 after transplantation with equal numbers of cells from the various lines indicated.

Sense FR cDNA and antisense FR cDNA were only distinct in the orientation of FR CDNA within (r)AAV. (iii) Integration of the sense and antisense FR cDNA-bearing RVS into the genome of $\mathrm{HeLa}-\mathrm{IU}_{1}$ cells was verified by restriction of genomic DNA and probing with ${ }^{32} \mathrm{P}$-labeled $n e o^{\mathrm{R}}$ and ${ }^{32} \mathrm{P}$-labeled FR cDNA. (iv) The demonstration that the integrated sense and antisense FR cDNAs were able to increase and reduce expression of endogenous FR RNA transcripts, respectively, was evidence of functional expression of the integrated genes. $(v)$ The changes of over- and underexpression of FR mRNA in sense and antisense cells, respectively, were reflected by proportionate changes in cell surface FR expression as measured by folate binding to intact cells at a temperature that prevents internalization of FRs in these cells $(30,41)$. Moreover, FACS analysis confirmed the likelihood that the changes in folate binding were a result of a net quantitative change in cell surface FRs in sense and antisense cells.

The total cellular FR content in sense or antisense cells was also altered proportional to the changes reflected in the FR mRNA and cell surface protein levels. The relative lack of effect with the antisense FR cDNA compared with untransduced cells suggests that the observed changes on the cell surface FR content in antisense cells are accompanied by a coincident perturbation of intracellular FR metabolism. Because net synthesis was primarily perturbed at the RNA level, these data therefore suggest that degradative pathways of FRs may be concomitantly altered (decreased in antisense cells?) following integration. Preliminary studies ${ }^{3}$ looking for alterations in the basal metabolism of FRs after transduction with antisense FR cDNA appear to support such a hypothesis. Furthermore, although there was no difference in folate binding for untransduced and antisense cells with time, the folate binding of sense cells increased approximately twofold more (Fig. 8) when compared with earlier data (Table I) (the interval between the performance of studies leading to the data in Table I and Fig. 8 was $\sim 2$ yr). We do not yet have an explanation for these results, but studies on potential changes in the metabolism of FRs in these cells are ongoing. ${ }^{3}$

Functional consequences of alteration of FRs. Despite the relatively weak expression of the transduced sense/antisense 
FR cDNAs, sense cells had an increase in doubling time and a reduction in overall cell proliferation in vitro. Because the potential variable of changes in cellular folate arising from altered cellular FR content was eliminated by cell culture in high extracellular folate concentrations, this ensured equivalent delivery of folate into all cohorts of cells used $(11,53)$. Thus, the observed proliferative differences were likely the result of independent effects of FRs and not a function of alterations in transmembrane folate delivery or intracellular folate content. Extension of these studies to nude mice also confirmed that the subtle alteration in cell doubling time and proliferation identified in vitro for sense cells was also reflected in reduced tumor volumes and greater than twofold prolongation of tumor doubling time when compared with either antisense and untransduced cells. Because the total solubilized FR contents of the cell lines analyzed in vitro were comparable with those removed from the tumors in vivo, these data served to rule out the possibility that transplantation led to alterations in cellular folate content to account for these findings. Moreover, because net FR content in sense cell tumors was twofold greater than that in antisense tumors, sense tumors would have accumulated more folate than antisense and untransduced tumors; thus, it was not possible to attribute the effects of reduced proliferation in vivo to folate deficiency in sense cells.

A not infrequent finding in biology is that data obtained in vitro often cannot be reproduced in vivo. In this light, the impressive prolongation of doubling time in vivo compared with tissue culture data (prolongation of doubling time from 96 to $226 \mathrm{~h}$ in vivo versus an increase in doubling time of 1 to 2 $\mathrm{h}$ in vitro) appeared almost incongruous and paradoxical. One possible explanation is that cells bathed in tissue culture media containing FCS are exposed to high concentrations of growth factors that are not normally present in vivo. Therefore, potentially subtle changes in cell proliferation among sense and antisense cells would not be detected until the concentration of growth factors in the tissue culture media decreased; this was indeed the case when growth conditions were switched from 10 to $2 \%$ FCS. Likewise, when propagated in vivo, these cells would not be exposed to high concentrations of growth factors as found in $10 \%$ FCS; this could have led to a further accentuation of differences in doubling time when compared with proliferation in vitro. Another explanation could be that single cellderived clones were used for in vivo studies, whereas mixtures of transduced cells within each cohort (of sense, antisense, and untransduced cells) were used for most of the in vitro studies. In fact, if each of the cohorts of sense, antisense, and untransduced cells were composed of a heterogeneous mixture of cells expressing varying amounts of FRs, and if there was an unambiguous inverse relationship between FR expression and cell proliferation, the in vitro data on cell proliferation would actually represent a significant underestimation, especially for sense cells. This is because the net results would primarily reflect the kinetics of the fastest proliferating (but relatively lower FR expressing) cells. Therefore, it was possible that a relationship between FR expression and cell proliferation could be strengthened if the pooled data from several randomly chosen, single cell-derived clones from sense and antisense cells could withstand such analysis.

The fact that there was little difference in FR expression and cell proliferation between different single cell-derived clones of untransduced cells highlighted the importance of our method of transduction of FR CDNA as a means of modulating
FR expression in these cells. More importantly, however, the data from randomly chosen single cell clone-derived cells transduced with sense and antisense FR cDNA supported the conclusion that there was an inverse relationship between FR expression and cell proliferation in these cells.

Because folate deficiency leads to megaloblastosis and premature cell death (1) and folate per se allows cells to proceed into the proliferative phase of the cell cycle, the higher folate content in sense cells in vivo should have been permissive for cell proliferation; however, the opposite finding was observed. This is apparently paradoxical, because a protein (i.e., FR) responsible for delivery of folates intracellularly (a growthpromoting function) appeared somehow to reduce overall cell proliferation. Because antisense cells had proliferative rates that were not significantly different from untransduced cells, the in vitro and in vivo data incriminate a folate-independent function of FRs in altering the cell doubling time of sense cells. A precedent for such findings can be found in our previous studies with primary hematopoietic progenitors, where anti-FR antibodies induced megaloblastosis and intracellular folate deficiency $(5,6)$ when incubated throughout culture. However, short-term interaction of anti-FR IgG with FR on these cells also led to a stimulation of cell proliferation $(5,6)$. Thus, although the mechanisms underlying these earlier observations still remain unclear, it is of interest that we have found that FRs clearly have a role in constitutive control of cell proliferation independent of their role in mediating cellular folate uptake in hematopoietic and malignant cells.

How can overexpression of FRs influence cell proliferation? Although speculative, we can consider some possibilities: $(i)$ Modulation of the quantity and distribution of intracellular folates by excess FRs (present in membranes lining intracellular organelles; reference 29) that can bind various folates (47) could have some influence in signaling changes in proliferation. However, because micromolar concentrations of folic acid in the growth media ensured its passive diffusion into these cells (53), the difference in distribution of folates would not be likely to be dependent on FR expression in sense versus antisense and untransduced cells. (ii) A large body of evidence implicates plasmalemmal caveolae (which are rich in GPI-anchored proteins) as the membrane locus where several molecules relevant to signal transduction are enriched (for review see reference 54). Although stimulatory signals have been primarily identified, the possibility that inhibitory signals can also be generated from caveolae that are rich in FRs (3) has not been entirely excluded; thus, FR overexpression in sense cells may be associated with such signals. (iii) Recent studies on our transduced cells indicate a consistent and biologically significant alteration in nucleoside diphosphate kinases and thymidine kinase in sense versus antisense cells. ${ }^{2}$ Therefore, it is possible that changes in intracellular nucleotides or the state of phosphorylation of proteins involved in the cell cycle could be modulated by similar changes that alter cellular kinases.

For malignant cells that constitutively overexpress FRs and can inversely regulate FRs in response to extracellular folate concentrations $(4,11,29)$ (i.e., reduced cell proliferation with up-regulation of FRs secondary to reduced extracellular folate concentrations), the present data suggest a simple model where these two apparently opposing (growth-promoting and growthinhibiting) functions of FRs could serve as a balance. In such a hypothetical model, the up-regulated FRs in response to extracellular folate deficiency could serve to check proliferation of 
cells by moving them into the resting phase of the cell cycle; this could serve to blunt the folate requirements of the cells during nutrient deficiency. Conversely, with nutrient (folate) excess in the extracellular fluid, down-regulation of FRs could concomitantly serve to release the normal inhibitory effects of FRs on cell proliferation, thereby leading to a permissive state for cell proliferation.

Although studies are underway to test the validity of this model, we stress that this hypothesis may have limited application for cells that exhibit reduced cell proliferation during FR up-regulation; this is because previous reports with $\mathrm{KB}$ cells $(11,55)$ failed to document changes in proliferation after adaptation to culture in low folate media. In contrast, during recent studies on the kinetics of synthesis and degradation of FRs in response to changes in the extracellular folate concentration with HeLa-IU $\mathrm{U}_{1}$ cells, ${ }^{3}$ we have identified a 1.4-fold prolongation of the doubling time following up-regulation of FRs in low folate media (compared with cells cultured in high extracellular folate concentrations). Whereas such data for HeLa-IU $\mathrm{I}_{1}$ cells are consistent with (but do not necessarily prove) the hypothesis for an inverse relationship between cell proliferation and FR expression, the earlier data with $\mathrm{KB}$ cells $(11,55)$ advises caution against extending this hypothesis to all cells. Factors that can explain differences in cell proliferation in response to the extracellular folate concentration may be because $(a)$ the $\mathrm{KB}$ cells used earlier $(11,55)$ were actually a mixture of $\mathrm{KB}$ plus HeLa cells $(31,32)$, whereas we used cloned cells that had prominent HeLa cell (but no KB cell) markers; and $(b)$ the "KB" cells used earlier $(11,55)$ are probably not GPI anchored based on biosynthetic labeling studies (56), whereas our HeLa-IU 1 cells contain GPI-anchored FRs consistent with an earlier report for the FRs of "KB"' cells (57). Nevertheless, if there was indeed an inverse relationship between FR expression and hematopoietic progenitor cell proliferation (in response to a reduction in extracellular folate concentrations), this would imply that the earlier observed increase in cell proliferation following interaction of hematopoietic progenitor cells with anti-FR antibodies $(5,6)$ may have been through neutralization or reversal of the constitutive inhibition of cell proliferation by FRs.

Together, the present studies and recent reports (58-60) that exploit the FR-mediated endocytotic pathway for delivery of folate conjugates (toxins or liposomes) into malignant cells (which constitutively overexpress FR) suggest that sense cells would proliferate more slowly and yet take up more folate conjugates. Thus, it is possible that there may be a role for direct injection of (r) AAV containing sense FR cDNA either into similar malignant tumors or into various compartments (such as the pleural, peritoneal, and meningeal spaces) containing these cells, or even by topical application of (r) AAV on diseased epithelial cells (of the skin or mucous membranes) with the intent to effect a modulation of FR expression; subsequent therapy with antifolates or toxic folate conjugates could increase cell kill of transduced cells.

\section{Acknowledgments}

We gratefully acknowledge the assistance of Dr. E. Srour in fluorescence sorting, Drs. P. C. Elwood, R. J. Samulski, R. H. Schloemer, S. H. Larsen, K. H. Fife, and K. I. Berns for generously providing plasmids/ viruses for this study, Dr. Nyla Heerema for carrying out karyotype analysis, and Dr. John Eble for histopathologic analysis of tumors.
This work was supported in part by grants CA 58919 from the National Institutes of Health (NIH) and DHP-120 from the American Cancer Society to A. C. Antony. B. R. Murphy was supported in part by NIH training grant DK 07519 .

\section{References}

1. Antony, A. C. 1995. Megaloblastic anemias. In Hematology: Basic Principles and Practice. R. Hoffman, E. J. Benz, S. J. Shattil, B. Furie, H. J. Cohen, and L. E. Silberstein, editors. Churchill Livingstone, New York. 552-586.

2. Henderson, G. B. 1990. Folate binding proteins. Annu. Rev. Nutr. 10:319335.

3. Anderson, R. G., B. A. Kamen, K. G. Rothberg, and S. W. Lacey. 1992. Potocytosis: sequestration and transport of small molecules by caveolae. Science (Wash. DC). 255:410-411.

4. Antony, A. C. 1992. The biological chemistry of folate receptors. Blood. 79:2807-2820

5. Antony, A. C., E. Bruno, R. A. Briddell, J. E. Brandt, R. S. Verma, and R. Hoffman. 1987. Effect of perturbation of specific folate receptors during in vitro erythropoiesis. J. Clin. Invest. 80:1618-1623.

6. Antony, A. C., R. A. Briddell, J. E. Brandt, J. E. Straneva, R. S. Verma, M. E. Miller, L. A. Kalasinski, and R. Hoffman. 1991. Megaloblastic hematopoiesis in vitro. Interaction of anti-folate receptor antibodies with hematopoietic progenitor cells leads to a proliferative response independent of megaloblastic changes. J. Clin. Invest. 87:313-325.

7. Matsue, H., K. G. Rothberg, A. Takashima, B. A. Kamen, R. G. Anderson, and $\mathrm{S}$. W. Lacey. 1992. Folate receptor allows cells to grow in low concentrations of 5-methyltetrahydrofolate. Proc. Natl. Acad. Sci. USA. 89:6006-6009.

8. Luhrs, C. A., C. A. Raskin, R. Durbin, B. Wu, E. Sadasivan, W. McAllister, and S. P. Rothenberg. 1992. Transfection of a glycosylated phosphatidylinositolanchored folate-binding protein complementary DNA provides cells with the ability to survive in low folate medium. J. Clin. Invest. 90:840-847.

9. Chung, K. N., Y. Saikawa, T. H. Paik, K. H. Dixon, T. Mulligan, K. H. Cowan, and P. C. Elwood. 1993. Stable transfectants of human MCF-7 breast cancer cells with increased levels of the human folate receptor exhibit an increased sensitivity to antifolates. J. Clin. Invest. 91:1289-1294.

10. Bottero, F., A. Tomassetti, S. Canevari, S. Miotti, S. Menard, and M. I. Colnaghi. 1993. Gene transfection and expression of the ovarian carcinoma marker folate binding protein on NIH/3T3 cells increases cell growth in vitro and in vivo. Cancer Res. 53:5791-5796.

11. Kane, M. A., P. C. Elwood, R. M. Portillo, A. C. Antony, V. Najfeld, A. Finley, S. Waxman, and J. F. Kolhouse. 1988. Influence on immunoreactive folatebinding proteins of extracellular folate concentration in cultured human cells. $J$. Clin. Invest. 81:1398-1406.

12. Mulligan, R. C. 1993. The basic science of gene therapy. Science (Wash. $D C)$. 260:926-932.

13. Blacklow, N. R. 1988. Parvoviruses and Human Diseases. CRC Press, Boca Raton, FL. 165-174.

14. Carter, B. J. 1992. Adeno-associated virus vectors. Curr. Opin. Biotechnol. 3:533-539.

15. Berns, K. I. 1990. Parvovirus replication. Microbiol. Rev. 54:316-329.

16. Muzyczka, N. 1992. Use of adeno-associated virus as a general transduction vector for mammalian cells. Curr. Top. Microbiol. Immunol. 158:97-129.

17. Samulski, R. J. 1993. Adeno-associated virus: integration at a specific chromosomal locus. Curr. Opin. Genet. Dev. 3:74-80.

18. Kotin, R. M., M. Siniscalco, R. J. Samulski, X. D. Zhu, L. Hunter, C. A. Laughlin, S. McLaughlin, N. Muzyczka, M. Rocchi, and K. I. Berns. 1990. Sitespecific integration by adeno-associated virus. Proc. Natl. Acad. Sci. USA. 87:2211-2215.

19. Kotin, R. M., J. C. Menninger, D. C. Ward, and K. I. Berns. 1991. Mapping and direct visualization of a region-specific viral DNA integration site on chromosome 19q13-qter. Genomics. 10:831-834.

20. Samulski, R. J., X. Zhu, X. Xiao, J. D. Brook, D. E. Housman, N. Epstein, and L. A. Hunter. 1991. Targeted integration of adeno-associated virus (AAV) into human chromosome 19. EMBO (Eur. Mol. Biol. Organ.) J. 10:3941-3950. Erratum appears in EMBO (Eur. Mol. Biol. Organ.) J. 11:1228.

21. Walz, C., and J. R. Schlehofer. 1992. Modification of some biological properties of HeLa cells containing adeno-associated virus DNA integrated into chromosome 17. J. Virol. 66:2990-3002.

22. Zhou, S. Z., H. E. Broxmeyer, S. Cooper, M. A. Harrington, and A. Srivastava. 1993. Adeno-associated virus 2-mediated gene transfer in murine hematopoietic progenitor cells. Exp. Hematol. 21:928-933.

23. Flotte, T. R., S. A. Afione, C. Conrad, S. A. McGrath, R. Solow, H. Oka, P. L. Zeitlin, W. B. Guggino, and B. J. Carter. 1993. Stable in vivo expression of the cystic fibrosis transmembrane conductance regulator with an adeno-associated virus vector. Proc. Natl. Acad. Sci. USA. 90:10613-10617.

24. Walsh, C. E., J. M. Liu, X. Xiao, N. S. Young, A. W. Nienhuis, and R. J. Samulski. 1992. Regulated high level expression of a human gamma-globin gene 
introduced into erythroid cells by an adeno-associated virus vector. Proc. Natl. Acad. Sci. USA. 89:7257-7261.

25. Elwood, P. C. 1989. Molecular cloning and characterization of the human folate-binding protein cDNA from placenta and malignant tissue culture (KB) cells. J. Biol. Chem. 264:14893-14901.

26. Samulski, R. J., L.-S. Chang, and T. Shenk. 1989. Helper-free stocks of recombinant adeno-associated viruses: normal integration does not require viral gene expression. J. Virol. 63:3822-3828.

27. McLaughlin, S. K., P. Collis, P. L. Hermonat, and N. Muzyczka. 1988. Adeno-associated virus general transduction vectors: analysis of proviral structures. J. Virol. 62:1963-1973.

28. Nahreini, P., and A. Srivastava. 1989. Rescue and replication of the adenoassociated virus 2 genome in mortal and immortal human cells. Intervirology. 30:74-85.

29. McHugh, M., and Y. C. Cheng. 1979. Demonstration of a high affinity folate binder in human cell membranes and its characterization in cultured human KB cells. J. Biol. Chem. 254:11312-11318.

30. Antony, A. C., M. A. Kane, R. M. Portillo, P. C. Elwood, and J. F. Kolhouse. 1985. Studies of the role of a particulate folate-binding protein in the uptake of 5-methyltetrahydrofolate by cultured human KB cells. J. Biol. Chem. 260:14911-14917.

31. Lavappa, K. S., M. L. Macy, and J. E. Shannon. 1976. Examination of ATCC stocks for HeLa marker chromosomes in human cell lines. Nature (Lond.). 259:211-212.

32. Lavappa, K. S. 1978. Survey of ATCC stocks of human cell lines for HeLa contamination. In Vitro. 14:469-475.

33. Verma, R. S., S. Gullapalli, and A. C. Antony. 1992. Evidence that the hydrophobicity of isolated, in situ, and de novo-synthesized native human placental folate receptors is a function of glycosyl-phosphatidylinositol anchoring to membranes. J. Biol. Chem. 267:4119-4127.

34. Antony, A. C., R. S. Kincade, R. S. Verma, and S. R. Krishnan. 1987 Identification of high affinity folate binding proteins in human erythrocyte membranes. J. Clin. Invest. 80:711-723.

35. Antony, A. C., C. Utley, K. C. Van Horne, and J. F. Kolhouse. 1981 Isolation and characterization of a folate receptor from human placenta. J. Biol. Chem. 256:9684-9692.

36. Sambrook, J., E. F. Fritsch, and T. Maniatis. 1989. Molecular Cloning: A Laboratory Manual. Cold Spring Harbor Laboratory Press, Cold Spring Harbor NY.

37. Srivastava, C. H., R. J. Samulski, L. Lu, S. H. Larsen, and A. Srivastava. 1989. Construction of a recombinant human parovirus B19: adeno-associated virus 2 (AAV) DNA inverted terminal repeats are functional in an AAV-B19 hybrid virus. Proc. Natl. Acad. Sci. USA. 86:8078-8082.

38. McCutchan, J. H., and J. S. Pagano. 1968. Enhancement of the infectivity of simian virus $\mathbf{4 0}$ deoxyribonucleic acid with diethylaminoethyl-dextran. $\mathrm{J}$. Natl. Cancer Inst. 41:351-357.

39. Hirt, B. 1967. Selective extraction of polyoma DNA from infected mouse cell cultures. J. Mol. Biol. 26:365-369.

40. Chomczynski, P., and N. Sacchi. 1987. Single-step method of RNA isolation by acid guanidinium thiocyanate-phenol-chloroform extraction. Anal. Biochem. 162:156-159.

41. Deutsch, J. C., P. C. Elwood, R. M. Portillo, M. G. Macey, and J. F. Kolhouse. 1989. Role of the membrane-associated folate binding protein (folate receptor) in methotrexate transport by human KB cells. Arch. Biochem. Biophys. 274:327-337.

42. Verma, R. S., and A. C. Antony. 1991. Kinetic analysis, isolation, and characterization of hydrophilic folate-binding proteins released from chorionic villi cultured under serum-free conditions. J. Biol. Chem. 266:12522-12535.

43. Smith, P. K., R. I. Krohn, G. T. Hermanson, A. K. Mallia, F. H. Gartner, M. D. Provenzano, E. K. Fujimoto, N. M. Goeke, B. J. Olson, and D. C. Klenk. 1985. Measurement of protein using bicinchoninic acid. Anal. Biochem. 150:7685. Erratum appears in Anal. Biochem. 163:279.

44. Freshney, R. I. 1983. Cloning and selection of specific cell types. In Culture of Animal Cells. A Manual of Basic Technique. R. I. Freshney, editor. Alan R. Liss, Inc., New York. 129 pp.

45. Zhen, W., H. N. Jayaram, and G. Weber. 1992. Antitumor activity of tiazofurin in human colon carcinoma HT-29. Cancer Invest. 10:505-511.

46. Blakley, R. 1969. The Biochemistry of Folic Acid and Related Pteridines. John Wiley and Sons, New York. 58-105.

47. Elwood, P. C., M. A. Kane, R. M. Portillo, and J. F. Kolhouse. 1986 The isolation, characterization, and comparison of the membrane-associated and soluble folate-binding proteins from human KB cells. J. Biol. Chem. 261:1541615423.

48. Woolson, R. F. 1987. Statistical Methods for the Analysis of Biomedical Data. John Wiley and Sons, New York. 243 pp.

49. Page, S. T., W. C. Owen, K. Price, and P. C. Elwood. 1993. Expression of the human placental folate receptor transcript is regulated in human tissues. Organization and full nucleotide sequence of the gene. J. Mol. Biol. 229:11751183. Erratum appears in J. Mol. Biol. 238:639.

50. Knecht, D. A., and W. F. Loomis. 1987. Antisense RNA inactivation of myosin heavy chain gene expression in Dictyostelium discoideum. Science (Wash. DC). 236:1081-1086.

51. Yokoyama, K., and F. Imamoto. 1987. Transcriptional control of the endogenous MYC protooncogene by antisense RNA. Proc. Natl. Acad. Sci. USA. 84:7363-7367.

52. Inouye, M. 1988. Antisense RNA: its functions and applications in gene regulation-a review. Gene. 72:25-34.

53. Antony, A. C., M. A. Kane, S. R. Krishnan, R. S. Kincade, and R. S. Verma. 1989. Folate (pteroylglutamate) uptake in human red blood cells, erythroid precursors and $\mathrm{KB}$ cells at high extracellular folate concentrations. Evidence against a role for specific folate-binding and transport proteins. Biochem. J. 260:401-411.

54. Anderson, R. G. 1993. Plasmalemmal caveolae and GPI-anchored membrane proteins. Curr. Opin. Cell Biol. 5:647-652.

55. Kane, M. A., R. M. Portillo, P. C. Elwood, A. C. Antony, and J. F. Kolhouse. 1986. The influence of extracellular folate concentration on methotrexate uptake by human KB cells. Partial characterization of a membrane-associated methotrexate binding protein. J. Biol. Chem. 261:44-49.

56. Elwood, P. C., J. C. Deutsch, and J. F. Kolhouse. 1991. The conversion of the human membrane-associated folate binding protein (folate receptor) to the soluble folate binding protein by a membrane-associated metalloprotease. J. Biol. Chem. 266:2346-2353.

57. Luhrs, C. A., and B. L. Slomiany. 1989. A human membrane-associated folate binding protein is anchored by a glycosyl-phosphatidylinositol tail. J. Biol. Chem. 264:21446-21449.

58. Leamon, C. P., and P. S. Low, 1992. Cytotoxicity of momordin-folate conjugates in cultured human cells. J. Biol. Chem. 267:24966-24971.

59. Leamon, C. P., I. Pastan, and P. S. Low. 1993. Cytotoxicity of folatePseudomonas exotoxin conjugates toward tumor cells. Contribution of translocation domain. J. Biol. Chem. 268:24847-24854.

60. Lee, R. J., and P. S. Low. 1994. Delivery of liposomes into cultured KB cells via folate receptor-mediated endocytosis. J. Biol. Chem. 269:3198-3204. 